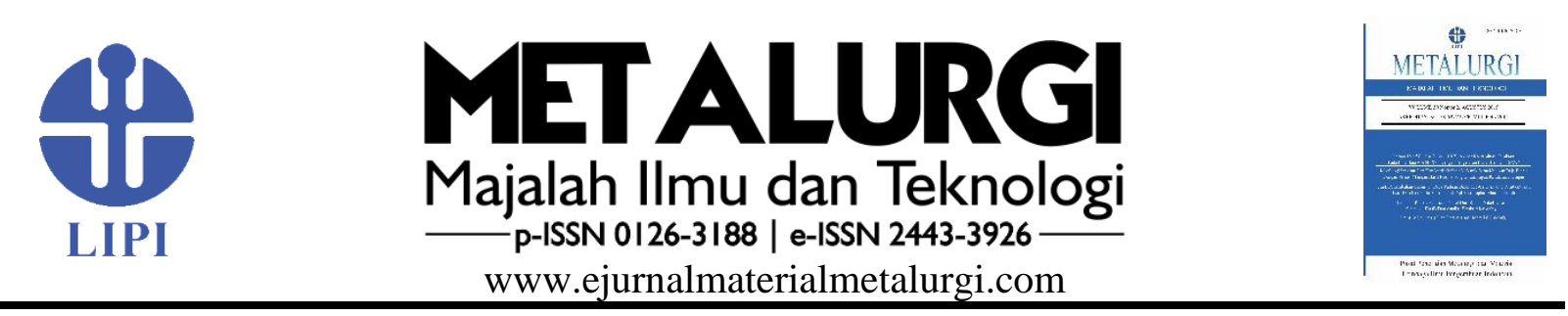

\title{
Mechanical Properties Enhancement of Al-Si-Cu-Fe Alloy Through Aging Treatment VARiations
}

\author{
Moch Iqbal Zaelana Muttahar*, Shinta Virdhian, Purbaja Adi Putra, \\ Dagus Resmana Djuanda, Eva Afrilinda, and Amsal Genesar \\ Balai Besar Logam dan Mesin, Kementerian Perindustrian \\ J1. Sangkuriang 12 Dago Bandung, Indonesia \\ *E-mail: mochiqbal@kemenperin.go.id
}

Masuk Tanggal :10-11-2020, revisi tanggal:02-12-2020, diterima untuk diterbitkan tanggal : 22-12-2020

\begin{abstract}
Abstrak
Paduan Al-Si digunakan secara lus sebagai komponen mesin menggantikan besi di beberapa bagian khususnya di industri otomotif. Beberapa sifat mekanik selalu menjadi pertimbangan dalam pemanfaatan paduannya. Pada penelitian ini dilakukan variasi perlakuan panas terhadap paduan $\mathrm{Al}-\mathrm{Si}-\mathrm{Cu}-\mathrm{Fe}$ meliputi solid solution treatment dan artificial aging. Paduan $\mathrm{Al}-\mathrm{Si}-\mathrm{Cu}-\mathrm{Fe}$ dipanaskan pada tungku dengan proses solid solution treatment pada temperatur $540{ }^{\circ} \mathrm{C}$ dengan waktu penahanan sekitar 5 jam dan proses quenching dilakukan pada temperatur $60{ }^{\circ} \mathrm{C}$ dengan media pendingin berupa air, dilanjutkan dengan 3 perlakuan aging yang berbeda yaitu single-stage aging, artificial aging dengan tahapan pre-aged, dan double-stage aging. Pengujian dilakukan melalui uji kekerasan, uji kuat tarik, uji impak, pengamatan metalografi dan SEM-EDS (scanning electron microscopy-energy dispersive spectroscopy). Hasil penelitian menunjukkan adanya perbedaan konstituen fase dan morfologi presipitat akibat variasi aging. Perbedaan masing-masing perlakuan terlihat pada morfologi endapan yang tersebar, yaitu berupa bentuk membulat dan menjarum, fasa ini dapat mempengaruhi sifat mekanik paduan Al-Si-Cu-Fe. Hasil pengujian mekanis menunjukkan kekerasan tertinggi diperoleh dengan perlakuan penuaan tahap ganda yaitu 161.27 HRB. Kekuatan tarik tertinggi terjadi pada spesimen dengan perlakuan penuaan satu tahap yaitu 202,56 MPa. Resistensi benturan tertinggi terjadi pada paduan dengan perlakuan pra-penuaan 18,6 J.
\end{abstract}

Kata Kunci: Paduan Al-Si-Cu-Fe, pre-aged, double aging, solid solution treatment

\begin{abstract}
Al-Si alloys are widely used as main engine components replacing iron in several parts in the automotive industry. Some of its mechanical properties were a reference in its alloy utilization. In this research, the heat treatment was carried out via solid solution treatment and artificial aging process. The alloy was heated in a furnace at $540{ }^{\circ} \mathrm{C}$ with holding time of 5 hours and quenched into water at $60{ }^{\circ} \mathrm{C}$ followed by 3 different aging treatments namely single-stage aging, artificial aging with pre-aged, and double stage aging. Characterization was carried out through hardness test, tensile strength test, impact test, metallographic and SEM-EDS (scanning electron microscopy-energy dispersive spectroscopy). This results showed the differences in phase constituent and morphology microconstituents due to aging variations. Each treatment's difference could be seen in the morphology of the precipitate that is dispersed, rounded, and needle-like shape. This phase can influence the mechanical properties of Al-Si-Cu-Fe alloys. The results of mechanical testing showed that the highest hardness was obtained by double stage aging treatment 161.27 HRB. The highest tensile strength was obtained in specimens with a singlestage aging treatment of $202.56 \mathrm{MPa}$. The highest impact resistance occurred in alloy with the pre-aging treatment of $18.6 \mathrm{~J}$.
\end{abstract}

Keywords: Al-Si-Cu-Fe alloy, pre-aged, double aging, solid solution treatment

\section{INTRODUCTION}

Al-Si alloys are widely used as main engine components replacing iron in several parts in the automotive industry [1]. This is supported by its superior casting properties, low density, excellent corrosion resistance, and high wear and heat 
resistance [2]. Al-Si casting alloys, including Al$\mathrm{Si}-\mathrm{Cu}$ and $\mathrm{Al}-\mathrm{Si}-\mathrm{Mg}$ alloys, have been widely applied because they can significantly reduce engine weight.

Infield conditions, casting alloys' mechanical properties are relatively lower and not yet ready to be applied to automotive components or other applications. Therefore, it is necessary to improve some mechanical properties of aluminum alloys in daily life, either through heat treatment or through alloying elements [2].

The mechanical properties of aluminum alloys depend on many factors, including alloys composition, casting method, cooling speed, the appearance of the iron intermetallic phase, and $\mathrm{Si}$ content of the alloys. A high level of Si can increase aluminum's ductility, provides strong resistance to aging, and tends to improve the size of intermetallics grains. However, the alloy's strength is related to the magnitude of $\mathrm{Mg}$ and $\mathrm{Cu}$ composition, and given heat treatment [3].

One of the heat treatments that can be done is a precipitation hardening, increasing the alloy by dissolving solid solutions through three main stages: solid solution treatment, quenching, and aging [4]. The mechanical properties obtained depend on the duration and temperature of the heating operation [5]. During heating, the alloy is heated to the solidus state to dissolve the second phase particles in the parent matrix for a certain period to reach one homogeneous phase before cooling from high temperatures. This process takes place between $170-200{ }^{\circ} \mathrm{C}$ and with a specific duration. The heat treatment that allows the homogenization process to form particles larger than $1 \mu \mathrm{m}$ significantly impacts the metal phase's evolution. It is suitable for the nucleation of particles [1]. As a result, dissolved atoms diffuse to form small deposits in the alloy matrix. This causes the Al matrix in the area of the particle to have a very tense tendency. This tight area becomes the point that triggers recrystallization [6].

The most recent research showed that the influence of heat treatment on $\mathrm{Al}-\mathrm{Si}-\mathrm{Cu}-\mathrm{Fe}$ alloy is found in the morphology of the $\alpha-\mathrm{Fe}$ (Chinese script) and $\beta-\mathrm{Fe}$ (needle-like) phase [3]. The increasing temperature of solid solution treatment involves silicon fragmentation and speroidization on dendritic Si. Another research found that aging treatment affects the corrosion resistance and hardness of $\mathrm{Al}-\mathrm{Si}-\mathrm{Cu}-\mathrm{Fe}$ alloys caused by the dispersion of precipitate after aging treatment [7].

Comparisons that occur due to aging treatments variations in pre-aging, single-stage aging, and double-stage aging in $\mathrm{Al}-\mathrm{Si}-\mathrm{Cu}-\mathrm{Fe}$ alloys have been observed and comprehensively studied are the focus of this research. Therefore, the purpose of this study is to determine the synergistic effects of various aging treatments on microstructure and changes in mechanical properties that occur mainly on tensile strength.

\section{Materials AND Method}

\subsection{Materials}

$\mathrm{Al}-\mathrm{Si}-\mathrm{Cu}-\mathrm{Fe}$ alloy was obtained through a casting process with pouring temperature at $690^{\circ} \mathrm{C}$, rotary argon degassing around 20 minutes, and dwell time degassing around 30 minutes. The raw material for this casting process came from $\mathrm{Al}-\mathrm{Si}$ ingot and aluminum scrap (mostly velg). Milling was conducted on the sample to prepare the specimen for composition testing with OES (optical emission spectroscopy). The composition of the alloy is shown in Table 1 [8]. The as-cast sample corresponded to the tensile test size with the addition of a riser on its top for around 50 $\mathrm{mm}$. At the end of the casting process, the riser was cut to get the proportional sample. The test piece for impact testing had a size of $25 \times 25 \mathrm{x}$ $170 \mathrm{~mm}$ (Figure 1), and then milling was done on the test piece to get a sample with a size of $10 \mathrm{x}$ $10 \times 55 \mathrm{~mm}$.

Table 1. Al-Si-Cu-Fe alloys composition

\begin{tabular}{cc}
\hline Element & $\begin{array}{c}\text { Weight } \\
\text { Percent (\%) }\end{array}$ \\
\hline $\mathrm{Al}$ & 88.80 \\
\hline $\mathrm{Si}$ & 6.38 \\
\hline $\mathrm{Fe}$ & 1.54 \\
\hline $\mathrm{Cu}$ & 1.21 \\
\hline $\mathrm{Mn}$ & 0.11 \\
\hline $\mathrm{Mg}$ & 0.06 \\
\hline $\mathrm{Cr}$ & 0.04 \\
\hline $\mathrm{Ni}$ & 0.11 \\
\hline $\mathrm{Zn}$ & 1.47 \\
\hline
\end{tabular}

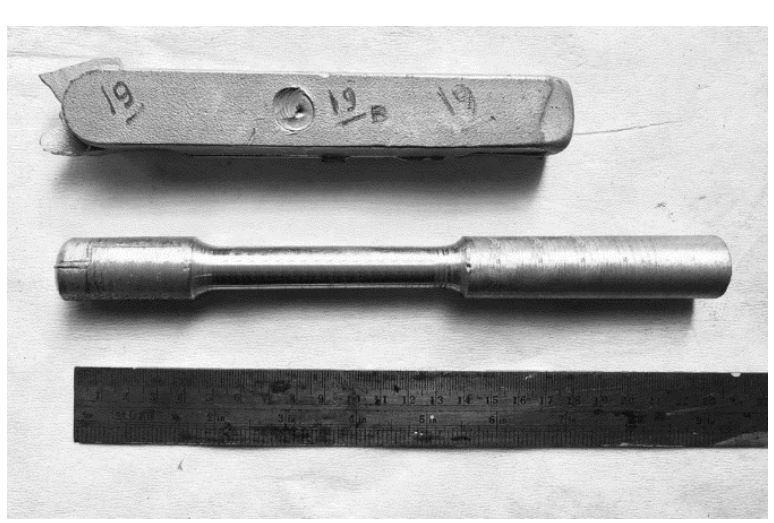

Figure 1. Specimen for tensile and impact testing

\subsection{Heat Treatment}

Specimens that had adjusted for their dimensions to the relevant test standards were 
heated in a furnace. This process is called solid solution treatment (SST) process. Heating was carried out at a temperature of $540{ }^{\circ} \mathrm{C}$ for 5 hours, followed by a quenching process using water quenchant at $65-80^{\circ} \mathrm{C}$ for 10 minutes [9]. In aging, the followed process was carried out with three aging treatment variations: pre-age treatment, single-stage aging, and double stage aging. The pre-aging process was done at a temperature of $100{ }^{\circ} \mathrm{C}$ for 1 hour. The artificial aging was carried out by heating the specimen to a temperature of $155{ }^{\circ} \mathrm{C}$ for 5 hours in the furnace. After the single-stage aging, double aging was carried out at a temperature of $180^{\circ} \mathrm{C}$ for 2 hours [7].

\subsection{Metallographic and SEM-EDS Observation}

Metallographic (Olympus DSX510) and SEM-EDS (JEOL-JCM 6000, single-phase $100 \mathrm{~V}$ AC, $50 / 60 \mathrm{~Hz}, 3.0 \mathrm{kVA}$ ) were observed to determine and analyze the phases formed in the matrix before and after the heat treatment process on the specimen. Samples were taken in separate blocks and made into a cube of $1 \times 1 \times 1 \mathrm{~cm}$. Etching reagent used in this research was Keller's reagent with a composition of $95 \%$ water, $2.5 \%$ $\mathrm{HNO}_{3}, 1.5 \% \mathrm{HCl}$, and $1 \% \mathrm{HF}$ [2].

\subsection{Tensile Strength and Hardness Testing}

The tensile test followed the JIS Z 2201 tensile test standard no. 5. Based on this standard, the length of the test specimen is $120 \mathrm{~mm}$, the gauge length is $50 \mathrm{~mm}$, and the gauge diameter is $14 \mathrm{~mm}$, as shown in Figure 2 [8]. The hardness test specimen was adjusted to the grip size of the tensile test specimen. Based on the standard, the hardness test specimen's diameter was $20 \mathrm{~mm}$, with a thickness of $10 \mathrm{~mm}$. Hardness testing was done using the Brinell method, followed by the JIS Z 2243 standard. The indentor used was 2.5 $\mathrm{mm}$, with an induced force of $62.5 \mathrm{kgf}$. The indentation was carried out for 10 seconds and three times, testing for each sample.

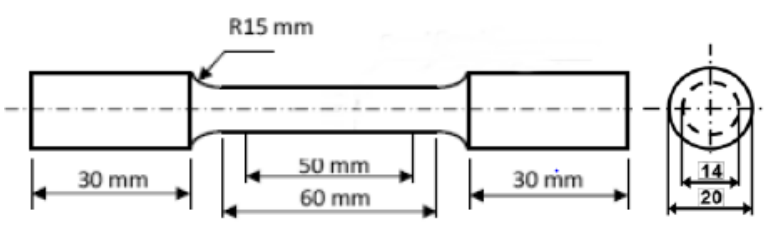

Figure 2. The dimension of tensile strength testing standard (JIS Z 2201)

\subsection{Impact Testing}

Impact test specimens were adjusted to the JIS Z 2242 impact test standard shown in Figure
3. Based on this standard, the size of the test specimens was $55 \times 10 \times 10 \mathrm{~mm}$ with $\mathrm{v}$-shaped notched and $45^{\circ}$ notch angles [8].
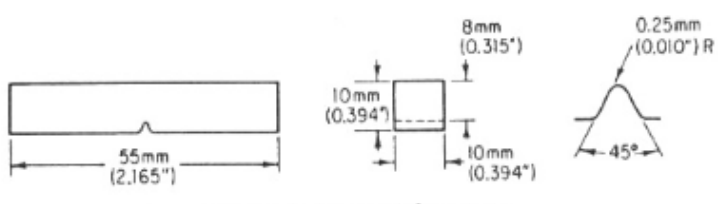

Figure 3. The dimension of impact testing standard (JIS Z 2242)

\section{RESUltS AND DISCUSSION \\ 3.1 Microstructure and SEM-EDS Observation Analysis}

Figure 4 shows the result of microstructure and SEM (sanning electron microscope) observation of $\mathrm{Al}-\mathrm{Si}-\mathrm{Cu}-\mathrm{Fe}$ alloy with various aging treatments. Figure 4(a) shows the microstructure of $\mathrm{Al}-\mathrm{Si}-\mathrm{Cu}-\mathrm{Fe}$ alloy without treatment with a bar scale of $50 \mathrm{~mm}$. It can be seen that there was a dendrite phase. This phase grew due to the effects of the casting solidification process. This dendrite is dominated by silicon, which is triggered by impurity particles. This mechanism occurs due to an unmodified alloy. It becomes a recurring reconnaissance interface that causes deviations formed due to cubic crystal twinning at the compaction interface [8].

It can be seen from Figure 4(b) that in the process of pre-aged silicon forms clusters and has decreased concentration in its phase. Silicon has not been dispersed evenly, so that the strength of the alloy is still relatively low. While artificial aging with pre-aged, there are AlFeSi phases and AlSi precipitates (EDS results in Table 2). SEM observations result for the specimen after the single-stage aging process can be seen in Figure 4(c). There is an $\alpha$-Al matrix, AlFeSi phase, and AlSi precipitates (EDS results in Table 2)

Table 2. EDS results of Al-Si-Cu-Fe alloy with artificial aging with pre-aged

\begin{tabular}{|c|c|c|c|c|}
\hline \multirow{6}{*}{$\begin{array}{l}\text { Pre- } \\
\text { Aging }\end{array}$} & Area & Element & Weight \% & Atomic \% \\
\hline & \multirow{3}{*}{ Spot 1} & $\mathrm{Al}$ & 62.96 & 72.33 \\
\hline & & $\mathrm{Si}$ & 12.98 & 14.32 \\
\hline & & $\mathrm{Fe}$ & 24.06 & 13.35 \\
\hline & \multirow{2}{*}{ Area 1} & $\mathrm{Al}$ & 43.24 & 44.23 \\
\hline & & $\mathrm{Si}$ & 56.76 & 55.77 \\
\hline \multirow{5}{*}{$\begin{array}{l}\text { Single- } \\
\text { Stage } \\
\text { Aging }\end{array}$} & \multirow{2}{*}{ Area 1} & $\mathrm{Al}$ & 26.24 & 27.02 \\
\hline & & $\mathrm{Si}$ & 73.76 & 72.98 \\
\hline & \multirow{3}{*}{ Spot 1} & $\mathrm{Al}$ & 86.76 & 90.59 \\
\hline & & $\mathrm{Si}$ & 5.48 & 5.50 \\
\hline & & $\mathrm{Fe}$ & 7.76 & 3.91 \\
\hline
\end{tabular}




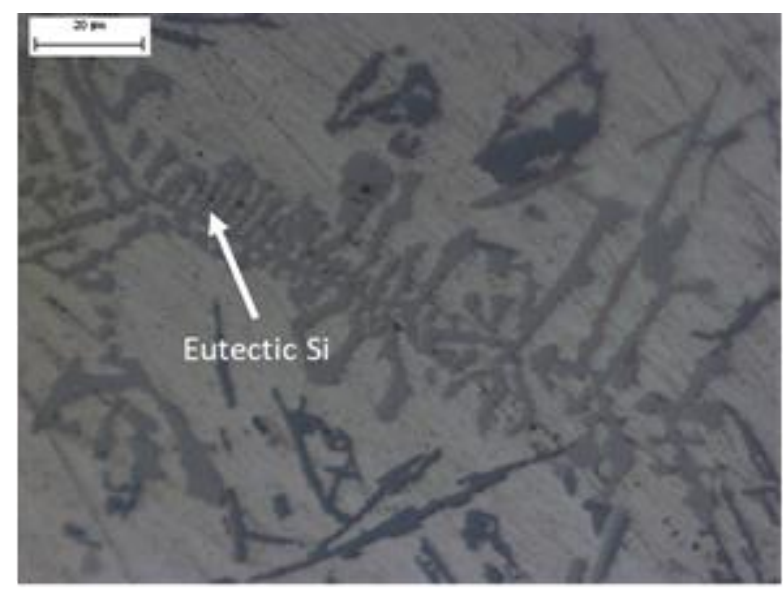

(a)

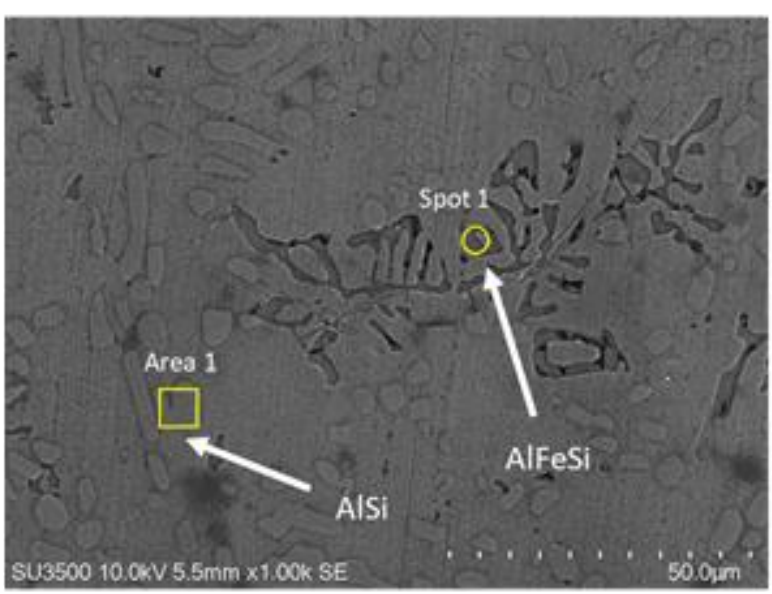

Figure 4. Microstructure of SEM results (a) As-cast Al-Si-Cu-Fe alloy (the bar scale is $20 \mathrm{~mm}$ ), (b) Artificial aging with pre-aged treatment (the bar scale is $50 \mathrm{~mm}$ ), (c) Single-stage aging treatment (the bar scale is $50 \mathrm{~mm}$ ), (d) Double-stage aging treatment (the bar scale is $50 \mathrm{~mm}$ ). Etched with Keller's reagent

Table 3. EDS results of Al-Si-Cu-Fe alloy with double stage aging

\begin{tabular}{lcccc}
\hline & Area & Element & Weight \% & Atomic \% \\
\cline { 2 - 5 } & & $\mathrm{Al}$ & 21.39 & 22.07 \\
\cline { 2 - 5 } $\begin{array}{l}\text { Double } \\
\text { Stage } \\
\text { Aging }\end{array}$ & Area 1 & $\mathrm{Si}$ & 78.61 & 77.93 \\
\cline { 2 - 5 } & & $\mathrm{Zn}$ & 2.40 & 1.01 \\
\cline { 2 - 5 } & Area 2 & $\mathrm{Al}$ & 91.53 & 93.06 \\
\cline { 3 - 5 } & & $\mathrm{Si}$ & 6.08 & 5.93 \\
\hline
\end{tabular}

In the single aging process for 5 hours, silicon has experienced dispersion and spheroidization seen in the rounded Si's morphology. The presence of heat in the furnace provides an opportunity for precipitates formed after the quenching process to spread and form spheres [3]. The difference between the two $\mathrm{AlFeSi}$ phases is on the morphology of its phase, where $\mathrm{Al}-\mathrm{Si}-\mathrm{Cu}-\mathrm{Fe}$ alloy with pre-aged treatment has a rounded shape; the specimen with singlestage aging has a Chinese script shape. According to Engler [10], the AlFeSi phase's

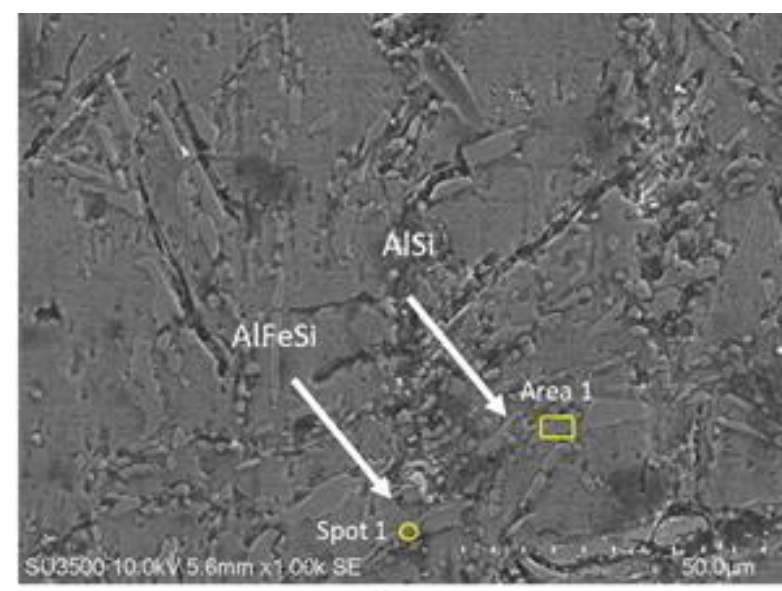

(b)

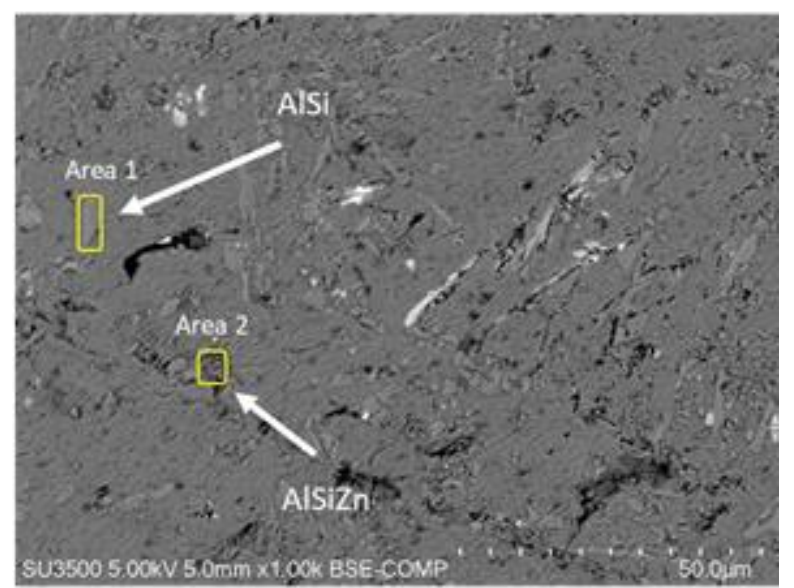

growth, among other phases, tends to cause the different phases to split and create clusters.

The SEM result of the double-aging process is shown in Figure 4(d). The presence of AlSi and AlSiZn precipitates is shown in Table 3. During the double aging process, the AlSi phase is deformed into finer grains. This phenomenon also occurs in Guo's research [11], which concluded that increasing heating time and increasing heating temperature resulted in increasing precipitate volume and affected its clustering. However, the precipitate elements remain. Furthermore, the phase is forced to grow with the existing element.

\subsection{Hardness Testing Analysis}

The results of hardness testing show that variations in aging affect the value of hardness of $\mathrm{Al}-\mathrm{Si}-\mathrm{Cu}-\mathrm{Fe}$ alloy. Figure 5 shows that the amount of hardness in the material has increased, influenced by the heat treatment process. The variation of aging treatment produces a significant change in the as-cast material's 
hardness. In the single-aging process, it gets a hardness value of $84.14 \mathrm{BHN}$. The increase in the hardness value is caused by the formation of the strengthening phase in the matrix. Ma [12] explained that about $0.5-1.3 \% \mathrm{Cu}$ content was able to increase the hardness in the aging process by up to $15 \%$. In artificial aging with pre-aged, the hardness value was $133.62 \mathrm{BHN}$, while in the double-aging process, 161.27 BHN. The result shows because precipitate dispersion has formed earlier so that the distribution can grow into finer phases at higher temperatures. Since the AlSiZn phase appears on the matrix, it contributes to increasing the hardness of the alloy [13].

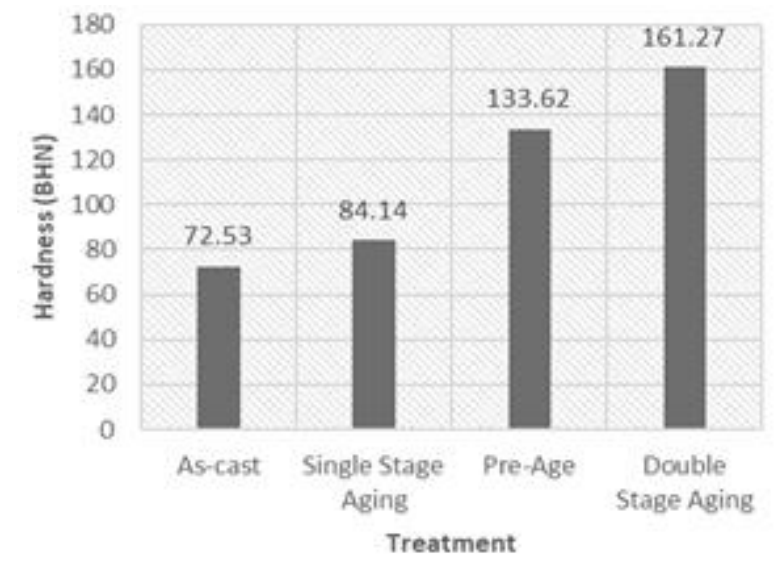

Figure 4. Hardness test result of $\mathrm{Al}-\mathrm{Si}-\mathrm{Cu}-\mathrm{Fe}$ alloy with different aging variations

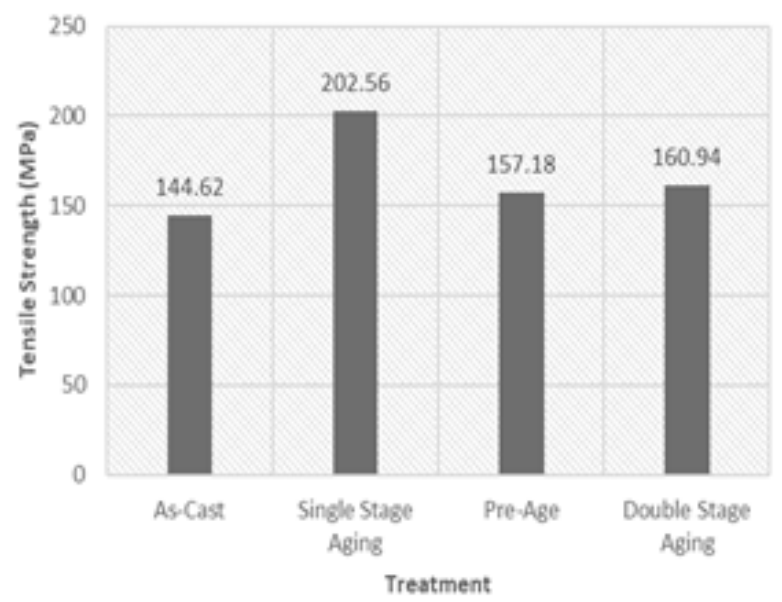

Figure 5. Tensile strength of Al-Si-Cu-Fe alloy with different aging variations

\subsection{Tensile Strength Testing Analysis}

Figure 6 shows the tensile strength values of $\mathrm{Al}-\mathrm{Si}-\mathrm{Cu}-\mathrm{Fe}$ alloy by several aging treatments. For materials with single-aging treatment, the tensile strength significantly changed from the as-cast material of $202.56 \mathrm{MPa}$. The artificial aging process with pre-aged and double-aging has increased to 157.18 and $160.94 \mathrm{MPa}$, respectively. Compared with the two tensile test results, the tensile strength value at double-stage aging is lower because of the over-aging process. This condition also happened in Umaru's research [13], which showed that the treatment of doubleaging at higher temperatures or longer time would result in over aging. In the single-stage aging treatment, uniformity of the microconstituents and the intermetallic phase experienced dispersion and regrowth so that some constituents were able to increase tensile strength [14]. Besides, the presence of $\mathrm{Cu}$ content in the alloy will increase the tensile strength but reduce the toughness [3].

\subsection{Impact Testing Analysis}

Figure 7 shows the impact resistance of Al$\mathrm{Si}-\mathrm{Cu}-\mathrm{Fe}$ alloy with different aging treatments. For material subjected to the pre-aging process significantly changes the impact resistance of ascast material, $18.60 \mathrm{~J}$. In contrast, it changes to 7.84 and $12.42 \mathrm{~J}$, respectively, for single-stage aging and double-aging processes. Because some of the precipitates have changed their shape from the Chinese script to a rounded shape, which is the most stable shape. A study conducted by Elsebaie [15] showed that the longer duration of aging would result in the expected softening of the alloy by its phase's growth or change of form, which had an impact on increasing the ductility properties associated with an increase in the total energy that was able to be absorbed by the alloy.

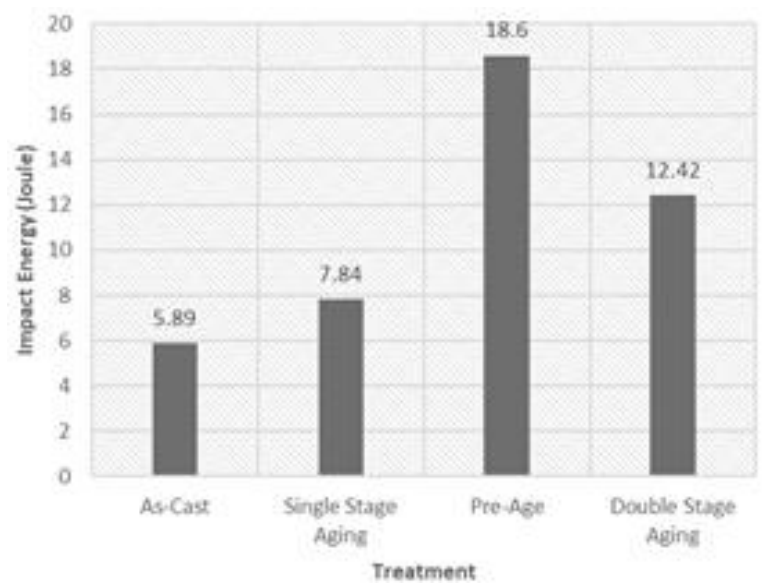

Figure 6. Impact toughness of $\mathrm{Al}-\mathrm{Si}-\mathrm{Cu}-\mathrm{Fe}$ alloy with different aging variations

\section{Conclusion}

The heat treatment process of $\mathrm{Al}-\mathrm{Si}-\mathrm{Cu}-\mathrm{Fe}$ with aging variations has been examined. The SEM results analysis showed that the microstructure appeared due to differences in aging treatment processes was the $\mathrm{AlSi}$ and $\mathrm{AlFeSi}$ phases. In the double-aging treatment process, other phases appear in the form of the AlSiZn phase. 
There was an increase in the mechanical properties of $\mathrm{Al}-\mathrm{Si}-\mathrm{Cu}-\mathrm{Fe}$ alloy due to the addition of aging treatment. The maximum increase value for hardness, tensile strength, and impact occurred of $120 \%, 40 \%$, and $210 \%$, respectively, higher than the as-cast $\mathrm{Al}-\mathrm{Si}-\mathrm{Cu}-$ Fe's mechanical properties.

\section{ACKNLOWLEDGEMENT}

Terima kasih kepada Direktorat Penelitian dan Pengabdian Masyarakat Universitas Indonesia atas dukungan finansial melalui hibah penelitian PITTA Universitas Indonesia tahun 2018.

\section{REFERENCE}

[1] J. G. Jeon, J. H. Shin, S. E. Shin, H. J. Choi, and D. H. Bae, "Recrystallized fine grains induced by nanoparticles in $\mathrm{Al}-\mathrm{Si}$ $\mathrm{Mg}-\mathrm{Cu}$-based alloy sheets," Mater. Charact., pp. 110457, 2020. Doi : 10.1016/j.msea.2020.139791

[2] B. Lin, H. Li, R. Xu, Y. Zhao, H. Xiao, and $\mathrm{Z}$. Tang "Thermal exposure of Al-Si$\mathrm{Cu}-\mathrm{Mn}-\mathrm{Fe}$ alloys and its contribution to high temperature mechanical properties," Integr. Med. Res., vol. 9, no. 2, pp. 18561865, 2019.

[3] S. Beroual, Z. Boumerzoug, P. Paillard, and Y. Borjon-piron, "Effects of heat treatment and addition of small amounts of $\mathrm{Cu}$ and $\mathrm{Mg}$ on the microstructure and mechanical properties of $\mathrm{Al}-\mathrm{Si}-\mathrm{Cu}$ and Al- Si-Mg cast alloys," J. Alloys Compd., vol. 784, pp. 1026-1035, 2019.

[4] M. Zhang, J. Wang, J. Han, H. Sui, and H. Huang, "Calphad optimization of heat treatment process of $\mathrm{Al}-\mathrm{Mg}-\mathrm{Si}$ cast alloys with $\mathrm{Zn}$ additions by simulation and experimental investigations," Calphad, vol. 67, pp. 101684, 2019.

[5] A. N. Singh, A. Moitra, P. Bhaskar, G. Sasikala, A. Dasgupta, and A. K. Bhaduri, "Effect of thermal aging on microstructure, hardness, tensile and impact properties of Alloy 617," Mater. Sci. Eng. A, vol. 710, pp. 47-56, 2018.

[6] A. L. Rominiyi, K. M. Oluwasegun, J. O. Olawale, M. B. Shongwe, and A. R. Adetunji, "Effect of post-ECAP aging on the microstructure, hardness and impact behaviour of 6061 Al alloy," Mater. Today Proc., In Press, 2020. Doi : 10.1016/j.matpr.2020.05.670.

[7] Y. Liu, Q. Pan, H. Li, Z. Huang, J. Ye, and M. Li, "Revealing the evolution of microstructure, mechanical property and corrosion behavior of 7A46 aluminum alloy with different ageing treatment," $J$. Alloys Compd., vol. 792, pp. 32-45, 2019.

[8] M. I. Z. Muttahar, "Pengaruh variasi temperatur dan waktu tahan (holding time) pada proses artificial aging terhadap struktur mikro dan kekerasan alumunium AC2C," Jurnal Informatika, Manajemen dan Teknologi, vol. 21, no. 2, pp. 77-86, 2019. Doi

10.23969/infomatek.v21i2.1979

[9] M. A. Afifi, Y. C. Wang, P. H. R. Pereira, and Y. Huang "Effect of heat treatments on the microstructures and tensile properties of an ultrafinegrained $\mathrm{Al}-\mathrm{Zn}$ Mg alloy processed by ECAP," J. Alloys Compd., vol. 749, pp. 567-574, 2018. Doi : 10.1016/J.JALLCOM.2018.03.206

[10] O. Engler, C. D. Marioara, Y. Aruga, M. Kozuka, and O. R. Myhr, "Effect of natural ageing or pre-ageing on the evolution of precipitate structure and strength during age hardening of $\mathrm{Al}-\mathrm{Mg}$ - Si alloy AA 6016," Mater. Sci. Eng. A, vol. 759, pp. 520-529, 2019.

[11] M. X. Guo, Y. D. Zhang, G. J. Li, S. B. Jin, and G. Sha, "Solute clustering in Al$\mathrm{Mg}-\mathrm{Si}-\mathrm{Cu}-(\mathrm{Zn})$ alloys during aging," Journal of Alloys and Compound, vol. 774, no. 5, pp. 347-363, 2018. Doi : 10.1016/j.jallcom.2018.09.309

[12] Z. Ma, E. Samuel, A. M. A. Mohamed, A. M. Samuel, F. H. Samuel, and H. W. Doty, "Influence of aging treatments and alloying additives on the hardness of Al11Si-2.5Cu-Mg alloys," Mater. Des., vol. 31, no. 8, pp. 3791-3803, 2010.

[13] O. B. Umaru, M. Abdulwahab, A. Tokan, A. M. Bello, and H. A. Umar, "Effect of double thermal ageing treatment on the mechanical properties of $\mathrm{Al}-\mathrm{Cu}-\mathrm{Mg} / 3 \%$ rice husk ash composite," Results Phys., vol. 6, pp. 342-345, 2016.

[14] A. M. Samuel, H. W. Doty, S. Valtierra, and F. H. Samuel, "Relationship between tensile and impact properties in $\mathrm{Al}-\mathrm{Si}-$ $\mathrm{Cu}-\mathrm{Mg}$ cast alloys and their fracture mechanisms," Mater. Des., vol. 53, pp. 938-946, 2014.

[15] O. Elsebaie, A. M. Samuel, F. H. Samuel, and H. W. Doty, "Impact toughness of Al$\mathrm{Si}-\mathrm{Cu}-\mathrm{Mg}-\mathrm{Fe}$ cast alloys: Effects of minor additives and aging conditions," Mater. Des., vol. 60, pp. 496-509, 2014. 